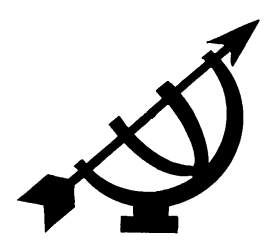

\title{
Flagging philosophical minefields at the Synod of Dort (1618-1619) - reformed Scholasticism reconsidered ${ }^{1}$
}

\author{
B.J. van der Walt \\ School of Philosophy \\ Potchefstroom Campus \\ North-West University \\ POTCHEFSTROOM \\ E-mail: benniejvanderwalt@gmail.com
}

\begin{abstract}
Flagging philosophical minefields at the Synod of Dort (16181619) - reformed Scholasticism reconsidered

This article investigates the phenomenon of reformed Scholasticism (of about 1550-1700), as it occurred at the Synod of Dort (1618-1619) and its Canons. More specifically, it focuses on the central problem at the Synod, viz. the relationship between God and human beings, as expressed in the ideas contained in the Canon regarding divine election and reprobation. As illustration the positions of two leading figures in the clash between the Calvinists and the Remonstrants, namely that of Gomarus (1563-1641) and Arminius (1560-1609), are philosophically analysed. In spite of the fact that neither viewpoint was eventually accepted by the Synod, their theologies clearly reflect the dominant scholastic philosophy of the time. This analysis is carried out in the context of the problemhistorical method of historiography developed by D.H. Th. Vollenhoven (1892-1978), one of the fathers of Christian philosophy.
\end{abstract}

1 This is a revised text from a paper delivered at the Vollenhoven Colloquium on 15 August 2011 at the Free University of Amsterdam, the Netherlands, prior to the International Symposium commemorating the 75th anniversary of the Association for Christian Philosophy. 
This contribution provides (in a series of other research publications, cf. 1.2.6 and bibliography) a final evaluation of the Synod and its Canons.

\section{Opsomming}

'n Uitwysing van filosofiese landmyne by die Sinode van Dordt (1618-1619): gereformeerde Skolastiek heroorweeg

Hierdie artikel ondersoek die fenomeen van die gereformeerde Skolastiek (van ongeveer 1550-1700) soos dit ook na vore gekom het tydens die Sinode van Dordt (1618-1619) en in die Dordtse Leerreëls. Dit fokus meer spesifiek op die sentrale probleem by die Sinode, naamlik die verhouding tussen God en mens soos dit tot uitdrukking kom in die Sinode se Leerreëls oor goddelike verkiesing en verwerping. Ter illustrasie word die standpunte van twee van die leidende figure in die stryd tussen die Calviniste en die Remonstrante, naamlik dié van Gomarus (1563-1641) en Arminius (1560-1609), filosofies geanaliseer. Hoewel die Sinode uiteindelik nie een van hierdie twee teoloë se standpunte aanvaar het nie, reflekteer hulle teologieë die skolastieke filosofie van destyds. Hierdie analise word gedoen volgens die probleem-historiese metode soos ontwikkel deur D.H. Th. Vollenhoven (1892-1978), een van die vaders van 'n Christelike filosofie.

Hierdie artikel (in 'n reeks van ander navorsingsartikels, vgl. 1.2.6 en die bibliografie) bied die outeur se finale evaluering van die Sinode en sy Leerreëls.

\section{Introduction}

A few notes about the motivation for this research, previous and present contributions in this field, and the organisation of this article are important.

\subsection{Motivation for the research}

Anno Domini 2011 one should, I think, explain why an article like this one - digging into the past of nearly 500 years ago - is still needed and relevant. I am doing so because of four main considerations.

\subsubsection{Personal interest}

The first one is of a personal nature. As a trained philosopher and theologian I am always interested in the relationship between Christian theology and Christian philosophy. 


\subsubsection{Mutual service between philosophy and theology}

Secondly, and more important, I am of the opinion that between (Christian) philosophy and theology there should be close cooperation, mutual service and enrichment.

In 1963 Vollenhoven (2011a:201-214) delivered a lecture at Potchefstroom, focusing on the service that a Christian philosophy could render to Christian theology. He emphasised inter alia that Christian theology cannot be practiced in "splendid isolation" from philosophy, since every theology (like all other disciplines) - whether one is aware of it or not - is influenced by deep-seated worldviewish and philosophical presuppositions; reformational philosophy can alert theologians to the dangers of synthetic-scholastic thinking; can warn against Biblicism; and it may also be of help to reflect on the appropriate field of investigation of Christian theology.

In spite of all these possibilities reformed theologies have, to my mind, not paid enough attention to reformational philosophy (an exception is the book by Van den Brink et al., 1997). There may be many reasons for this sad state of affairs, for instance difficulties theologians experience in grasping Stoker's, Dooyeweerd's and Vollenhoven's philosophy; the vehement reaction of scholastic theologians (like Hepp) during the 1930s against a Christian approach in philosophy; ecclesiastic schisms in the Netherlands; the lack of time to read outside one's discipline; increased specialisation; and (later on) also increased secularisation.

\subsubsection{Reformed Scholasticism is (still) alive}

This article may easily be viewed as unfair, since critique is usually easier in hindsight. One may respond to what is said here by saying: "The theologians at Dort were - as we are also today - children of their times and could not formulate their ideas otherwise." Such criticism, however, is only half the truth. In view of the fact that today many reformed churches worldwide still accept the Canons of Dort, they should also keep in mind that to be truly reformed requires continuous reformation (ecclesia reformata semper reformanda est).

This brings me to the next reason or motivation for writing this article. The golden age of reformed Scholasticism or orthodoxy (c. 1550-1700) is not something of the past at all. I can mention examples of this kind of theology in sermons in South Africa and elsewhere, as well as in articles in the periodicals of some reformed churches. Since the Canons of Dort (CD) are still accepted as confessional standards by many reformed churches worldwide, and 
even have to be subscribed to by ministers, elders and deacons as in full agreement with the Scriptures, debates about the authority of the CD continue. Some contemporary reformed theologians are of the opinion that the form (wording) may be deficient, but the basic content should not be challenged. (A reply to this unsatisfactory view will be provided at the end of this article in 5.3.)

One example that illustrates that reformed Scholasticism is very much alive is what is materialising at Calvin Seminary and College, Grand Rapids (Michigan, USA). Reformed theologians at this institution of reformed churches in the US and Canada, like Muller (2003), are republishing the old writers of the reformed orthodoxy and present their ideas in a very uncritical way in books regarding this period (cf. also Muller, 2008). In addition, some Christian philosophers at Calvin College (e.g. Smith, 2004) even attempt to combine in a postmodern style reformational philosophy with radical orthodoxy (which is to my mind, a regression to medieval Scholasticism).

This kind of neo-Scholasticism is, however, not limited to the United States. It is gaining influence in the Netherlands (cf. Van Asselt \& Dekker, 2001; Sinnema, 2002:157-160) and even in South Africa (cf. Kruger, 2011).

\subsubsection{A tribute to Vollenhoven's pioneering philosophy}

My fourth consideration in writing this article is that it aspires to be a tribute to Professor Vollenhoven (1892-1978): a recognition of his development of a genuine Christian systematic philosophy, and in particular for his Christian analysis - the only real analysis we have after 75 years - of the entire history of Western philosophy.

As indicated by Tol (2010), the young Vollenhoven initially also found his own thinking in the grips of reformed Scholasticism - albeit a qualified one - called "critical realism". It must have been a huge spiritual struggle to liberate himself from such a powerful synthetic philosophy. As a result, he had to bear the brunt of fervent criticism from the theologians of his day. For this reason I'm convinced that Vollenhoven's thetical-critical philosophy can be of great help to strengthen reformational thinkers - philosophers and theologians against the powerful seduction of the contemporary resurgence of reformed Scholasticism. 
Although Vollenhoven (as far as I know) never wrote explicitly on the Synod of Dort (SD) or its Canons (CD), he left enough clues - to be followed up in this article - of what his evaluation would have been.

\subsection{Previous and present research}

Following is some brief information about orthodoxy and Scholasticism; then a short review of the different interpretations of reformed orthodoxy or Scholasticism; followed by an indication of the writer's own viewpoint; and, finally, his previous research.

\subsubsection{Orthodoxy and Scholasticism}

Although I may at times use the two terms (reformed) orthodoxy and (reformed) Scholasticism as interchangeable, they should be distinguished.

As the word itself indicates orthodoxy places a strong emphasis on the correct doctrine. Usually the religious doctrines of orthodox people are regarded by them as universal, irrefutable and applicable to every time and place. In what follows, we will keep this in mind, but concentrate on the scholastic element of reformed Scholasticism.

Varied definitions for Scholasticism are proposed by different scholars (to be dealt with by the author in a forthcoming article). The term is derived from the Latin scholasticus, indicating a medieval teacher or student. The phenomenon of Scholasticism was inter alia characterised by a conservative, traditional approach to the sources studied; a strictly logical way of thinking; the use of a specific methodology; and clearly influenced by a reinterpretation of the philosophy of Aristotle (cf. Spykman, 1992:24-26). The term scholastic (in e.g. scholastic theology) was widely used by reformed scholastic theologians themselves.

Orthodoxy and Scholasticism thus entails the following practical implications: Christian faith eventually becomes primarily a system of theological beliefs to be maintained and subscribed to, lacking genuine heart-centred and powerful renewal. As Vander Stelt (2012) puts it, preaching came to depend on dogmatics, emotions on reason, subjective experiences on objective doctrines, pastors on theologians, and denominations on theological seminaries.

\subsubsection{Different interpretations}

Before any philosophical analysis of the CD can be done, one should be aware of the fact that contemporary literature about re- 
formed Scholasticism reflects at least three different interpretive models (cf. Van Asselt, 1996:128 ff.). The first is the discontinuity theory of decline as well as two theories of continuity, viz. a negative and a positive one. The reference points of these models are, on the one hand the sixteenth-century Reformation, and medieval theology on the other.

The first (discontinuity) theory perceives a clear break between the Middle Ages (c. 500-1500) and the Reformation (c. 1500-1550), as well as between the Reformation and reformed Scholasticism (c. 1550-1700). The two continuity models, however, see a continuous development from the Middle Ages through the Reformation towards Protestant orthodoxy. The positive continuity theory does not accept any decline, break or discontinuity during the long history of Christianity from AD 500 to present day.

The negative continuity theory, however, is a kind of mixture between the discontinuity and positive continuity theory. In agreement with the discontinuity theory, the negative continuity theory regards reformed Scholasticism as a break with the Reformation. Additionally, however, it also shares the view of the positive continuity theory, namely that remaining scholastic-medieval elements on which later orthodoxy could build, cannot be denied in the theology of the sixteenth-century Reformers.

\subsubsection{The author's viewpoint}

If my own viewpoint has to be categorised according to Van Asselt, it would correspond with the negative continuity theory. This theory reflects more or less my own tradition of a reformational philosophy. Both Vollenhoven (1933:316-317) and Dooyeweerd (1949:11) were critical about reformed Scholasticism's synthetic thinking.

It should be kept in mind that the theory according to which one interprets Scholasticism goes hand in hand with one's definition of this phenomenon. Whereas Van Asselt and other contemporary theologians view it merely as an acceptable, rational-systematic method, Vollenhoven (2011b:86) regards it as a synthesis between biblical and unbiblical ideas. While early Christian, patristic thinking was a spontaneous kind of synthesis between the Bible and pagan philosophy, the Scholasticism of the Middle Ages and subsequently was a more deliberate synthesis. The radical difference between these two sources (pagan philosophy and God's Word) was also relativised. Plato and Aristotle were declared to be $50 \%$ Christian in their 
philosophies, with the result that the Word of God lost its directive or guiding role.

\subsubsection{Form (method) cannot be isolated from content}

The author's main problems with Van Asselt (1996) and other theologians (cf. Te Velde, 2010a \& 2010b) are, firstly, that they regard Scholasticism merely as a method of theologising, and secondly, that they view a method as something neutral. Thirdly, they are of the opinion that the scholastic philosophical method determined only the form and not the content of reformed orthodoxy. As a consequence (lastly), they are not in a position to see the real, unbiblical philosophical influences, or totally underestimate them. (At the end of this article, in 5.5, we will return to this unacceptable separation between form/method and content.)

\subsubsection{The Canons of Dort}

For brief introductions on the SD and the CD one may consult Nauta (1957) and Polman (1959). In the case of the CD one finds the same diverse contemporary interpretive methods as the ones mentioned under 1.2.2 above (cf. also Sinnema, 1986:467 ff.). On the one hand, some scholars today view Dort as the triumph of Scholasticism, while others confine the scholastic influence only to the formal or methodological facet of the CD, and therefore underestimate the real influence of scholastic philosophy. The issue therefore deserves closer investigation.

In concluding this point on the various interpretations of reformed Scholasticism in general and the CD in particular, it should be mentioned that not all theologians are as uncritical as Van Asselt, Te Velde as well as the previously mentioned Muller (2003).

The research of Graafland (1987a; 1987b; 1996 \& 2001) is one example of a reformed theologian who strongly denies the idea that philosophical influences on the reformed theologies and confessions can be limited to mere formal facets. (Philosophy is foundational to theology and cannot be regarded as a mere servant, providing neutral methodological "tools" to theology.) Graafland, therefore, detects clear unbiblical influences in reformed orthodoxy - the CD included.

\subsubsection{Previous research of this author}

For my master's thesis in Philosophy (cf. Van der Walt, 1968) I already applied Vollenhoven's consistent problem-historical method. It dealt with the philosophy of Thomas Aquinas in his Summa contra 
Gentiles. In this way I got acquainted with medieval scholastic thinking. For my doctoral dissertation I again, with the help of Vollenhoven's historiographical method, analysed Aquinas' thinking, as well as Calvin's and that of the Synopsis Purioris Theologiae (SPT) of 1625 (cf. Van der Walt, 1974). Following the doctrinal struggles at the SD, the SPT was written as a "purified" theology by four reformed professors at the University of Leiden.

It was only recently that I had the time to look at the period between Calvin and the SPT, namely reformed Scholasticism in general (c. 1550-1700) and the Synod of Dort (1618-1619) in particular. Several articles were already published or will soon appear in Afrikaans (cf. Van der Walt, 2011a; 2011b; 2012a; 2012b). This contribution in English is intended for a wider audience.

\subsection{Organisation of this investigation}

This article will be developed according to the following main points: firstly, a brief explanation of Vollenhoven's philosophical "minesweeper" that will be applied in this research; secondly, the theological "minefields" at the Synod and in the Canons of Dort, as well as a detection of their hidden philosophical "landmines"; thirdly, their "detonation" from a reformational philosophical perspective; and lastly, some final conclusions.

\section{The consistent problem-historical method as a philosophical "minesweeper"}

To explain Vollenhoven's "minesweeper", attention is required for his philosophical method, his own development, the outlines of his philosophical historiography, and its application to the present research.

\subsection{Vollenhoven's thetical-critical method}

Vollenhoven's own systematic philosophy and his analysis of Western philosophical concepts should not be viewed separately (Vollenhoven, 2005a:6-8). Vollenhoven emphasises that one cannot philosophise without a preliminary own thetic: "Here I tentatively take my stand"-viewpoint. At the same time he also stresses the fact that one should critique, evaluate and seriously consider results of the Western history of philosophy. "Critical" does not imply only rejection, since in criticising one's own thetical perspective one can test and even enrich it. 


\subsection{Vollenhoven's development}

Regarding the thetical side of his methodology, Vollenhoven already started changing his own views from 1923 on, rejected scholastic thinking around 1926, and finalised his own systematic position at about 1930, with only minor changes up to the 1941 edition of his Isagôgè Philosophiae (cf. Tol, 2010:8, 13, 15, 20).

From then onwards he struggled to acquire an appropriate method for the critical part of his philosophy. According to Bril (1986:181 ff.) Vollenhoven's semi-final concept of a method was - after five previous efforts - only ready in 1943. It was more or less rounded off in his Schematische kaarten (1962; republished in Vollenhoven, 2000) as well as in his guest lectures at Potchefstroom in 1963 (cf. Vollenhoven, 2011b). He, however, continued till he was too old to "cut and paste" on the "warp" and "woof" of the complicated "weaving" of Western philosophy. He also did not have the time to update his own systematic philosophy. (Perhaps one can try to do so today by carefully studying his analysis of other's philosophies.)

\subsection{Vollenhoven's historiography in a nutshell}

Since Vollenhoven's method has been explained by himself and many others, I only have to repeat very briefly its basic outlines, following mainly the clear exposition by Bril (1986), one of the experts on Vollenhoven's methodology. (The details can be found in Vollenhoven, 2005b; 2005c.)

In Vollenhoven's own systematic philosophy a basic distinction is made between the structures of cosmic reality and their direction. In agreement with this, his historiographic method distinguishes between different types and different currents of Western philosophy. Types indicate a thinker's view on the ontic structures of reality, while currents describe his/her commitment to a specific normative direction of thinking. Every serious thinker, according to Vollenhoven, has to reflect firstly on what is, and secondly, on how one ought to think and act.

\subsubsection{Structural types}

A type is like a magnet: it attracts (or repels) certain themes around itself. If we apply the image to a cloth, one can call types the white threads. These vertical threads (the ontic core or nucleus) "colour" the cluster of ideas attached to it. 
The same type may recur during the history of Western thought, and therefore reflects a certain continuity, a "family resemblance" between the different philosophies of different ages. We may therefore find today, for example, a similar type of philosophy as that advocated by Plato or Aristotle about 2500 years ago. But since it is not identical to the original viewpoints of Plato or Aristotle, they should be called Platonising or Aristotleising concepts, or Plato-/Aristotle-interpretations. (In the case of reformed orthodoxy, some biblical ideas were of course added.)

Vollenhoven distinguished about nineteen different main types and many more subtypes of philosophy in Western history (cf. Vollenhoven, 2005b:161-163; 2005c:157-159).

\subsubsection{Periods or currents}

Vollenhoven's two-dimensional historiography identifies, apart from the above diachronic element, also a synchronic aspect. The woven cloth of Western intellectual thinking includes, apart from the white (vertical) "warp", also the red (horizontal) "woof" of different periods or currents of thought. These reveal a thinker's idea of law, order, normativity or values. They indicate the "spirit" of a period. Examples are Rationalism (from about 1600-1900), containing different subcurrents, or irrationalism, or contemporary Postmodernism.

While the types of worldviews and philosophies have a more constant character (they can pop-up again throughout history), the philosophical views about normativity changed throughout history they are responsible for the dynamic character in the patterns of the Western mind. Vollenhoven distinguishes about 60 such currents in Western philosophy (cf. Vollenhoven, 2005b:157-160 \& 2005c:153156).

Structure (type) and direction (current) should be distinguished, but ought not to be separated. Stated differently: fact and value are closely connected. One can illustrate this in the following way. To describe something as "a murder" is not simply stating a fact, but implies also the value that a murder is something wrong. Or a simple traffic stop sign is not merely a brute physical fact, but contains a normative prescription to a driver.

The implication is that, although the same type of philosophy may reappear during a later phase in history, it will to some extent be transformed according to the new spirit or current in which a thinker is philosophising. (To continue with our previous metaphor: the red 
"woof" can change the white "warp" to pink.) An example is that a reformed scholastic type of thinking may reappear in a new garb in the contemporary postmodern philosophical current long after its heyday from 1550-1700. We may then indicate it as reformed neoScholasticism (cf. 1.1.3 above).

In conclusion: the conception of a thinker consists of two aspects, viz. a specific type of philosophy, as well as the current it reflects. This method can be visualised (as in Vollenhoven, 2000:184-259) in diagrams consisting of intersecting horizontal lines (for different currents) and vertical lines (indicating the various types of philosophy).

Many thinkers, however, developed during their lifetime by moving to a different type or a new current or to both. (An example is the complicated development of Aristotle's philosophy.)

\subsection{Application to the present study}

The above methodology will now be applied to an analysis of the Canons of Dort (CD). It will focus on a central problem at Dort, viz. the relation between divine sovereignty and human responsibility. As illustrations of two clashing philosophical viewpoints at the Sinod of Dort (SD), Gomarus and Arminius will be used. (More information about these two prominent figures at the SD is provided in Graafland, 1987a; 1996:54 ff. 186 ff.; Kunz, 1996; Dekker, 1993.)

For brevity, only the main results of the research can be mentioned. For further details the reader is referred to the author's other publications already mentioned under 1.2.6, especially Van der Walt (2012a), which provides from a philosophical perspective a detailed analysis of the CD in its original Latin version. (For the Latin text, cf. Schaff, 1983 and for an English translation of 1986, cf. CRC, 1987.)

\section{The landmines identified by a philosophical minesweeping of Dort}

In this second main section the following points will be attended to: the background, the main conclusion, the wrong direction and wrong type of philosophy in the $C D$, and the unsolved problem of the relationship between God and man.

\subsection{The background}

Van der Walt (2011b) gives a general overview of the theological struggles of Augustine, Aquinas, Calvin, Beza, Ursinus and the 
Synopsis to gain clarity about the divine-human relationship. This overview clearly indicates the influence of the Aristotelian "revolution" (different Aristotle interpretations) from the time of Beza (15191605) onwards.

The theological doctrines and their underlying philosophical viewpoints of two prominent figures at the SD, F. Gomarus (1563-1641) and J. Arminius (1560-1609), are discussed in Van der Walt (2011a). Brief introductions on the life and work of Gomarus and Arminius are provided by Van Itterzon (1958:278-280; 1956:329-331).

In Van der Walt's forthcoming articles (2012a; 2012b) it will be indicated that no real solution could be given to the issue of God's sovereignty and human responsibility. The SD tried to compromise different speculative views, accepting a slightly modified late-medieval solution.

This article summarises the research of these articles (to be published), builds on them by adding new sources and insights, as well as drawing the final conclusions of the whole series.

\subsection{Main conclusion: not the Bible but often unbiblical philosophy had the final word}

One should keep in mind that the SD employed the philosophical insights of many past centuries at their disposal in trying to solve a vexing problem. Simultaneously it searched in a biblicist way in the Bible for guidance.

Unfortunately they (both the orthodox and heterodox theologians) read the Bible through spectacles coloured by some unbiblical philosophical presuppositions. Consequently, God's revelation lost its true guiding role. Looking at the differences between Gomarus and Arminius it is clear that the struggle was not primarily between a correct interpretation of the Bible (the Calvinists) and a wrong interpretation (the Arminians). It was rather a deep-seated clash between different (unbiblical) philosophies. (Reading the CD in its original Latin terminology enhances the identification of its underlying philosophy.)

\subsection{The philosophical influences}

A summary of the most important conclusions of the research done thus far follows. While the analysis will be mainly philosophical, it will 
also, when appropriate, refer the reader to contemporary, supporting theological research.

\subsubsection{A wrong (synthesis) direction}

Vollenhoven did not identify the period of 1550-1700 in reformed thinking as a separate period or (sub)current. Perhaps this is because it was a mixture of medieval Scholasticism, the sixteenthcentury Reformation, and early scientistic Rationalism. Rationalism hypostatised the human mind as Reason to become the directive for human thought and practice. Scientialism overvalued the scientific over and against the practical reason, and, therefore, reveals a strongly speculative nature.

In addition, the Calvinists and Arminians at Dort were synthetic thinkers trying to accommodate ancient pagan (Aristotleising and Platonising) philosophy (as found in revived Thomism), as well as the contemporary early Rationalism with the Scriptures, often considered as a textbook for theology. Since these Christians' loyalty was divided between at least three philosophical normative directions plus that of God's Word, their theologies could not provide clear guidance any more.

This complex synthesis was achieved by way of two methods. The first method was eisegesis-exegesis, which in a biblicistic manner read foreign ideas into a biblical text, and then read such ideas out of the Scriptures - now with biblical sanction. The second one was the method of nature-supernature (or grace). Its consequence was a compromise between what can be believed and reasoned - between theology (as the queen) and philosophy (as merely a servant to theology).

The rationalistic tendency at the SD and the CD is evident from the strong speculative character of their theologies. In agreement with their view of theology (i.e. the scholarly study of God), even God was regarded as the object of rational analysis. Theologians had to describe exactly how God is ontologically structured, how his intellect and will operate, et cetera. They were not satisfied with his revelation about Himself in his Word.

Apart from an unclear, wrong direction, a wrong type of philosophy also underlies the CD. 


\subsubsection{A wrong type of philosophy underlying the Canons}

A whole cluster of ideas about the ontological structure of God and cosmos, as well as their mutual relationship influenced reformed scholastic theology at the time of Dort. Among them were the following:

\section{- A dualistic ontology}

The CD clearly accepts only one reality divided in a higher and lower part: God (= transcendent) and cosmos (= non-transcendent). In such a kind of ontology the tendency is either to emphasise the divine (transcendent) or the human (non-transcendent). When this happens, God and humans could become competitors. Either divine sovereignty or human responsibility is one-sidedly emphasised or even abandoned. Or, to avoid these extremes, one attempts to maintain an uneasy, often unstable balance between them. God and man then become cooperators - with the basic problem unsolved, since one then has the problem of how much God and how much a human being has to contribute in the process of salvation.

\section{- An all-determining God as the first cause}

The resurgence of various interpretations of Aristotle (among both Catholics and Protestants in the writings of inter alia Melanchthon, Ramus, Suarez, Zabarella) had a decisive influence on the following facet of reformed orthodoxy: a hierarchically-structured view of being, in which God is regarded as the unmoved mover and final cause of everything.

In his hierarchical ontology Aristotle regarded his god as the apex of all movement (cf. Lovejoy, 1973:24 ff.). Since everything moves, there should be a final, unmoved mover. Aristotle's god moves everything to itself. However, because its highest pleasure is only to think about itself, this god is in no way concerned about the cosmos. It is merely the first ontic cause of everything, without any religious relationship to mankind. Those ideas were Christianised by the great medieval scholastic thinker, Thomas Aquinas (cf. Den Ottolander, 1965), and modified where necessary. Because the theologians who gathered at Dort were Christians, they also tried to modify, but could not get rid of such an idea about God and its deterministic implications for creation, man included. (A biblical critique of such scholastic and unbiblical ideas about God is provided by inter alia Peels, 2000 and Van Eck, 1997.) 


\section{- Two different methods based on the same ontology}

In agreement with the above ontological starting points (God and cosmos), two main methods were acknowledged at the time of Dort. In theological discourse the synthetic (a priori) method was used, which argued from causes to their consequences - in other words from God to the cosmos. Or, the popular (a posteriori) so-called analytic method (for "ordinary" believers) was used, which followed the opposite direction, namely from the effects backwards through intermediary causes and ultimately to the final cause, God. This, I think, was similar to the circular routes followed (according to a dualistic ontology) by the so-called supernatural and natural theologies of the medieval past - from God to creation or from creation back to God (cf. Aertsen, 1982 \& 1991).

In reformed Scholasticism these two methods were usually called the scholastic method and the popular method (cf. Van 't Spijker, 1990). The scholastic method was important for learned men and young students at a theological academy, while the popular method was significant for the common, uneducated and illiterate people in the churches. The scholastic method was compact, rigorous, focused on intellectual proofs, arguments and knowledge of the truth. It was intended to provide certainty. The popular method was diffuse, expansive, rhetorically free and focused on arousing good will, moving the emotions, and providing comfort to ordinary believers. In spite of the fact that it was decided that the popular method should be followed at Dort, the scholastic approach was clearly present.

\section{- A static view of creation}

While the theologians at Dort acknowledged that the cosmos was the creation of God, it was viewed as static, eternally determined by an all-determining God. They thought cosmologically and could, therefore, not fully acknowledge the genesis, development of creation, or the cultural task God gave man to fulfil his responsibility in unfolding the potential of creation. Both their idea about God and their view about mankind, therefore, resulted in hampering human responsibility. It encouraged passivity, quietism, resignation, the acceptance of a preordained divine resolution. This deterministic view was strengthened further by a next important idea.

\section{- The "hidden" idea about law}

Because of their synthetic thinking (cf. 3.3.1 above) the theologians of the time missed the biblical idea of God's law as the order (boundary and bridge) to which his whole creation is subjected and 
through which life should be directed. They did not clearly distinguish God's law-order either from God or from his creation. According to a long preceding tradition (starting with Plato, further developed by Aristotle and Hellenistic philosophy, and the neo-Platonism of Augustine) the law was regarded as simultaneously existing ante rem (before creation), in the mind of God (in mente Dei); in rebus (in every created thing); and post rem (through abstraction in the reason of human beings - the clear influence of early rationalism). On the one hand, law was confused with God (and God with law), while on the other hand, it was (as thing-laws) confused with creation (or creation with order). In both cases the law lost its real nature and character as God's guiding rule for the direction of life.

This idea of the law in God intensified the deterministic character of reformed Scholasticism. It was called God's eternal plan, decision or decree, according to which He predestined everything on earth, including the election and reprobation of humans. Taking this as a starting point, theologians only differed on the order within God's decree - whether He elected/reprobated after Adam and Eve fell into sin (called infralapsarianism), or even before their creation (called supralapsarianism).

It should be noted that this scholastic idea about law not only resulted in a deterministic view of creation, but God became its captive, subjected to his own law or decree. It further strengthened the idea of God as static, unmovable (Deus immutabilis). He not only did not, but could not change his rational decree or will!

\section{- The universal-individual distinction and its implications}

Another idea complementing the whole cluster of this type of scholastic thinking was how these theologians viewed the relationship between the individual aspects (e.g. this tree) and its universal side (e.g. trees in general). They were neither individualists (who regarded the individual aspect of primary importance), nor universalists (the reverse viewpoint - the individual derived from the primary universal), but partial universalists (the universal and individual stand either in a vertical or horizontal relationship to each other).

Scholastic thinkers usually preferred the vertical relationship between the universal and individual, but did not totally agree among themselves. Some scholastics (the intellectualists) regarded the universal as the higher and the individual as the lower one, while others (the empiricists) proposed exactly the opposite viewpoint: the lower one was the universal, while the higher was identified with 
individuality. Examples of this difference were the viewpoints of Gomarus (an intellectualistic semi-mystical thinker) and Arminius (an empiricist).

\section{- Arminius's viewpoint}

It should be remembered that Arminius became critical of the rigid and abstract Aristotelian logic and methodology used by his teachers, Beza and Gomarus. He also studied for some time in Padua (Italy) with the famous Zabarella (1555-1589), an internationally renowned logician. Zabarella's new logic boils down to his belief that a person moves logically from what is practical to what is abstract; from what is known to the unknown; from what is analytical to what is synthetical (cf. the two methods described above); or from the Scriptures to dogmatics - not vice versa.

This less abstract, more practical and easier method accepted by Arminius also moved from human faith to the divine decrees, from man to God, or from what is individual to what is universal. As a result, Arminius ascribed priority to what is individual, and regarded the place and responsibility of human reason and free will as more important than was the case with Gomarus.

In spite of the fact that Arminius's viewpoint was labelled by the CD as Pelagianism, it was not correct. The difference between the two was that Pelagius (a consistent empiricist) overvalued the human aspect, while Arminius (an inconsequent empiricist) still tried to give divine sovereignty and supernatural revelation its full due.

\section{- A dichotomistic anthropology}

In spite of the fact that the theologians at the SD had different views on exactly when God's decree was fulfilled (prior or after his eternal decree), most of them accepted the above idea about God and his eternal decree. The variations became more obvious when one considers their differing views of being human, because in dualistic thinking the relationship between God and man is not determined only by God, but also from the human side.

This is clearly illustrated in a comparison of the anthropologies of Gomarus and Arminius. Gomarus believed that part of the human being (his intellect, the highest part of the soul) is derived from the transcendent God and can be united with Him again. I have described this viewpoint as (intellectualistic) semi-mysticism ("semi" since not the entire human being, but only his/her intellect contains a divine element). Such a viewpoint is not too concerned about one's 
responsibility here on earth, but primarily about a mystic, intellectualistic unification with God. It, therefore, merely strengthens the already-mentioned quietism, resignation and passivity.

Janse (1937), however, sees an absolute antithesis between mysticism and real biblical communion with God, and rejects the mystical interpretation of biblical texts of some reformed theologians. According to him a distinction between true (= biblical) and false mysticism is therefore nonsensical.

Vollenhoven (2005b:37 \& 2011b:35) is also very critical of any form of mysticism, since it blurs the radical ontic difference between God and human beings. In mysticism the relation of the human being to God is regarded as that of the individual to the universal. The Bible, however, nowhere teaches a mystical - ontological - relationship with God, but a religious, covenantal relationship. Mysticism, therefore, implies the death of genuine biblical religion. However, even today so-called Christian mysticism is alive and well if one consults the recent book of Van Schaik (2005).

In contrast to Gomarus's mysticism, Arminius, as inconsistent empiricist, puts more emphasis on the human will and human responsibility. Compared to Gomarus's intellectualism, he may be called a voluntarist, since to him one's will is not determined by the intellect (reason), but the other way around.

\section{- Conclusion: Aristotle redivivus?}

If the landmines identified above are real, the last surprising discovery I have made is that they were not at all new in 1619. If Vollenhoven is correct, the philosophical viewpoints of Arminius and Gomarus were (apart from their Christian orientation) similar to two phases of Aristotle's philosophy during the latter part of his life (cf. Vollenhoven, 2000:197, 198, 254), viz. inconsequent empiricism and semi-mysticism. This should not be a surprise, since many studies have emphasised the Aristotelian renaissance in Europe from about 1500-1650.

\subsubsection{Unsolved problems}

Finally, the CD did not accept the viewpoints of either Gomarus or Arminius, but it contains as a compromise a slightly modified latemedieval solution for the problems surrounding divine sovereignty and human responsibility (cf. Sinnema, 1985:459). Many crucial problems therefore remained unsolved (cf. Sinnema, 1985:430 ff.). 
These problems regarding the relationship between God and man the result of the type of synthetic philosophy underlying the CD continued to haunt believers and divide churches up to the present day, since they did not remain merely abstract speculations. A few examples are the following:

\section{Problems from the side of one's idea about God}

- Is God really such a far-off, uninvolved, static being, or is He according to his own Word a dynamic God of love, with compassion for his creatures?

- Is the whole idea of an eternal, divine decree not totally unbiblical speculation? In asking such a question, I am not questioning the overwhelming evidence throughout the Bible that God Almighty guides the lives of everyone. God even rules over unbelievers like Pharaoh, by hardening his heart (Exod. 10:1; Rom. 1:28). When people do wrong to someone (like Joseph's brothers), God in the end may even use it to the benefit of the same wrongdoers (Gen. 45:5; 50:20)! His power - unlike humans' power - is not limited by human sin or even the devil. Why should we then try to bind Him to an eternal decree? Why not simply stick to the word of Paul: " $\ldots$ in all things God works for the good of those who love Him ..." (Rom. 8:28)?

- Is it correct to view God as the captive of his own law or decree? God is faithful to his laws, but not subjected to them as his creation is.

- Logically speaking, it seems as if God (the first cause of everything) is also the cause of sin and reprobation. What then about the Bible that tells us that God hates sin?

- If God decreed from eternity, even before we were born, who will be rejected or saved, what then was the sense of sending Jesus Christ as our saviour, calling everyone to come to Him and be saved?

- What could be the sense of preaching the gospel to those already rejected from eternity?

\section{Problems with the human side}

- Does this kind of theology not severely undermine human responsibility? Don't we also have a responsibility towards, for instance, our conversion and sanctification? 
- On the one hand, a person who believes to be elected from eternity may become careless and passive (compare question 64 of The Heidelberg Catechism: "But doesn't this teaching make people indifferent and wicked?").

- On the other hand, one may be a Christian, but nonetheless experience great anxiety because of the always-present possibility of already being rejected by God from eternity.

\section{The detonation of some landmines at Dort}

Firstly, an alternative for the direction and then for the type of philosophy at Dort will be discussed.

\subsection{An alternative direction}

The preceding exposition has hopefully indicated how powerful and deceptive the synthetic-scholastic spirit was at Dort. It should also be clear that the synthetic direction of the SD and its Canons could not really solve its central problem: it could not indicate a clear normative direction in the relation between man and God because of its alliance with a mixture of Aristotelian, medieval, rationalist and biblical tendencies and a consequently divided normative loyalty. But even more, it confused, scared and paralysed many Christians; it caused ecclesiastical schisms. Most important of all, it obscured the real message of God's Word.

Every kind of synthesis therefore has to be rejected. But we should also be aware of why people tend to think in this way - especially in the light of the resurgence of scholastic thinking among reformed people today (cf. 1.1.3).

\subsubsection{Some reasons for synthetic thinking}

Various reasons can be mentioned for the permanent popularity of synthetic thinking (cf. Vollenhoven, 2011a:198). Some Christians are not even aware of the fact that they try to combine biblical and unbiblical ideas in their thinking. Yet, others do so consciously because they want to be regarded as "with it", in line with the (secular) spirit of their time. For yet another group it is the easiest way out as consistent reformational thinking, in obedience to God's threefold revelation, is not easy. A fourth group of people egoistically are of the opinion that to be critical of and opposed to the spirit of their age is too demanding. However, the final result is always detrimental. As a Christian thinker one may try to accommodate or Christianise Plato, Aristotle or a postmodern philosopher's ideas. The outcome, 
however, is that your own philosophy or theology is annexed by the pagan Aristotle or a modern-day secular thinker.

We are reminded by Vollenhoven (2011b:75-76) that synthetic thinkers were not pagans, but Christians and should be honoured as such. (This may also be a reason why some theologians today seem to be less aware of the mixed philosophical background of the CD or reformed scholastic thinking in general.) Simultaneously, Christian synthetic thinking has a great appeal and has a strong, tempting and seductive power, which makes it difficult to acknowledge its dangers. The motivation behind synthesis may have been with good intentions, but the results are not in keeping with genuine, biblicallyobedient thinking.

\subsubsection{Not antithetical}

If I understand Vollenhoven correctly, he was, however, not an antithetical but a (thetical) antisynthesis thinker. He did not simply propose his own viewpoint as correct and final, and (antithetically) rejected all others out of hand. One of the aims of his involvement in the history of Western philosophy was not simply to criticise, but to learn from others, and if possible, to enrich his own viewpoint (cf. 2.1).

\subsubsection{Also the methods employed rejected}

The SD's stated intention was that God's Word, the Bible, should have the final word. It became clear, however, that because of the biblicist and nature-grace methods employed, the true Word of God was obscured. A biblicist approach sometimes expects too much from the Bible and therefore often declares more than what the Bible teaches. In contrast it can also ask too little from God's Word and therefore says less than what God reveals, minimising its directive power. In both cases its message is muffled. The greatest danger, however, is that one reads into the Bible one's own pre-conceived conceptions about God and the human being. The Bible becomes the puppet and the human reader its ventriloquist. Even the slogan sola Scriptura can be misleading. Thus, to insist on the importance of the Scriptures in scholarship is not to take it primarily as another source or additional information, but to deem it infallible in its orientating and direction-providing role.

Put differently: Christians are not supposed to look biblicistically into the light of Scripture - in the same way I am at this moment not looking into the light of my reading lamp, but I am writing with its 
illumination. (Limited place does not allow me to discuss here God's threefold creational, inscriptured and incarnated revelation and their relationship.)

In addition, the second method employed at Dort - that of distinguishing a lower realm of nature and a superior realm of supernature (grace) - has to be rejected. This entails a confusion between structure and direction, since according to such a dualist view of creation, a part of the world (the natural, e.g. politics) is regarded as intrinsically neutral or even evil, while the higher part (grace, e.g. church life) is viewed to be by nature good, and the only realm in which one can really be related to and serve God. In such a viewpoint Christian faith simply becomes an "add on" instead of a comprehensive renewing force in life. (For the better viewpoint, cf. Vollenhoven, 2011b:87.)

\subsubsection{The most important directive}

I have indicated already that the directional and structural aspects of one's life should neither be confused nor be separated. The directional aspect is missing at the SD and in the CD - or rather, due to its mixed loyalties (e.g. to Greek, medieval, rationalistic philosophies and the Bible) they reflect clashing normative directions. This confusion is strengthened by the CD's emphasis on the ontological relationship instead of on a religious relationship between God and humankind (cf. semi-mysticism above, which aspires to an ontic union with God, as well as 4.2.1).

Together with this, as I see it, goes a lack of emphasis not only on God's love for humankind, but also on God's central and foundational command to us to love Him and our fellow humans. This command, diversified into many forms of love (like fidelity in a marriage, love for one's children or parents in a family, honesty in business and justice in politics), should be the central directive force in one's entire life, emphasising our human responsibilities in different areas.

\subsection{An alternative type of philosophy as a basis for theology}

I will only briefly indicate a sounder alternative (for the details, cf. Vollenhoven, 2005a and the second part of Van der Walt, 2012b).

\subsubsection{Alternative to a dualistic ontology}

In the place of a two-factor ontology (a dualist ontology), Vollenhoven - this is the "hallmark" of his philosophy - proposes a clear 
distinction and close relationship between three factors, namely God, his creation, and his law-order for creation. God's laws function both as a boundary and as a bridge between God and the creation, subjected to his law-words.

God's central law of love - and not an eternal decree - governs the relationship between Himself and humankind. God loves us and as religious beings we have to respond with love by being obedient to his laws.

- Vollenhoven, therefore, firstly does not view the relationship between God and humans as an ontological one, but as religious in character. He defines religion as follows: "... religion is the relationship of humankind to the God of the covenant in obedience or disobedience to his fundamental law of love" (Vollenhoven, 2005a:76).

- Secondly, religion to him is not confined to the sphere of grace (above a secular domain of nature), but one's entire life is religious in nature, service to - and not union with - God.

- Thirdly, when we replace a dualistic ontology (one with a transcendent and non-transcendent part) in this way, there is no need to visualise God and man either as competitors or cooperators. Our complete dependence on God and our relative and responsible independence go hand in hand. Also God's law does not lessen our human accountability for the course of our lives - it rather heightens it. Precisely because God is the sovereign giver of law, we are the more responsible (cf. Spykman, 1981:186). Janse (1939:154) too argues convincingly that, according to the Bible, no contradiction exists between God's election and human responsibility.

\subsubsection{Alternative to an all-determining God}

God is not a Deus immutabilis at all. He goes along with human history. An example is that He felt sorry not only for those created in his image, but even for the animals in Nineveh and changed his mind about destroying the entire city.

God, therefore, did not decide in a deterministic way from eternity the lot of every creature, but continually reveals Himself throughout history in new ways. When one follows the biblical line of creationfall-redemption-consummation this is very clear. His covenantal word was already at the beginning (creation) a two-sided "yes" (in the case of obedience to his law) and a "no" (when disobedient). At 
the fall his judgement ("no") became a reality, but also, his election ("yes"). From the beginning, in his single word of love, election was a revelation of his mercy, and reprobation a revelation of his justice. But election is always the "overtone" (He does not wish for anyone to perish), and reprobation the "undertone" (cf. Spykman, 1981:190).

God the Father also fully revealed his will in Jesus Christ. We do not have to look speculatively behind Christ for a hidden, eternal decree.

\subsubsection{Alternative to a static view of creation}

Vollenhoven rejects (purely) cosmological thinking, since it entails not a dynamic but a static ontology. If God is not a Deus immutabilis, why should He create a fixed, static world? He created it to unfold (from a garden to a city), and to be developed by human beings his vicegerents on earth - who in this way also develop themselves. The biblical message is not quietist passivity, but responsible activity in God's world. Human beings have a calling to walk with God in every aspect of their lives - from the past, through the present, towards the future.

\subsubsection{An alternative to scholastic realism}

As already indicated, in the CD God's law was dissolved in God, in creation and the human mind, whereas Vollenhoven regards it as a separate reality, given by God to be obeyed by his creatures. In such a perspective the idea of an eternal, divine, deterministic decree is not needed. God is also no longer subjected to his own law, reason or will, but stands above it. This does not mean that $\mathrm{He}$ is not faithful to his commands - He blesses obedience and punishes disobedience.

Simultaneously, the door is fully open to human responsibility - flourishing in obedience and suffering divine judgement if not.

To summarise: God the Father created everything and established his laws; the Son indicates the basic direction (of love); and the Holy Spirit guides us towards obedience. Human beings have the responsibility to concretise God's love command in different professions and social relationships. In this way love flourishes in many colours in human life.

\subsubsection{An alternative for the individual-universal debate}

The universal and individual are aspects Vollenhoven considers to be part of every created being - he rejects all the above-mentioned 
theories about what they are (e.g. separate entities), how they are related to each other, and also the idea that God is viewed as "something" universal.

\subsubsection{An alternative to a dichotomist anthropology}

As already indicated, a specific anthropology plays an important role in how a person views his relationship with God. Tol (2010:224 ff.) indicates how Vollenhoven, influenced by Janse's "holistic" anthropology, changed his whole philosophy and, therefore, also his view on the divine-human relationship. Limited space does not allow me to give even the barest outline of Vollenhoven's more biblicallyoriented anthropology (cf. Van der Walt, 2010:259-409 for details). Suffice it to mention only the following:

- According to Vollenhoven, a human being is a multidimensional being, reflecting about fifteen different irreducible facets. To be human does not involve only two components, viz. body and soul, or intellect and will. To be renewed in the image of God, does not imply becoming more spiritual or divine, but simply to obey God's commandments.

- Vollenhoven rediscovered the biblical meaning of the heart as the religious centre of being human, determining the whole direction of one's life. It replaced the speculation about a mystical unification with God and also the age-old debate about the dominance of either will or intellect.

- He rejected the higher-lower distinction of soul and body in favour of the more biblical inner-outer distinction between heart and functions.

- Vollenhoven's distinction between human structure and direction is of great value. When applied to the debate at Dort about a "free will" it offers a solution. Structurally and functionally our will is free, yet directionally it is not freed from the bondage of sin. It is an "enslaved freedom" - unless one is liberated by the grace of God to obey his laws.

- Every human being has a divine office, called and tasked in this world - a huge responsibility!

\section{Final conclusions}

A few results of this and previous investigations are the following: 


\subsection{Biblical and unbiblical elements}

The result of Christian synthetic, scholastic thinking is always a blend of biblical and unbiblical elements. The focus of this article was mainly on some unbiblical philosophical presuppositions accepted during the Synod at Dort. One should, however, not discount some genuine biblical perspectives in the Canons authored at Dort. A few examples are the following:

In II, 5 one reads the following:

$\ldots$ it is the promise of the gospel that whoever believes in Christ crucified shall not perish but have eternal life. This promise, together with the command to repent and believe, ought to be announced and declared without differentiation or discrimination to all nations and people, to whom God in his good pleasure sends the gospel. (Italics - BJvdW.)

In III, 8 the following appears:

... all who are called through the gospel are called seriously ... seriously $\mathrm{He}(\mathrm{God})$ also promises rest for their souls and eternal life to all who came to Him and believe (italics - BJvdW).

And in III/IV, 16 we hear the following:

... just as by the fall man did not cease to be man, endowed with intellect and will, and just as sin, which has spread through the whole human race, did not abolish the nature of the human race but distorted ... it, so also the divine grace of regeneration does not act in people as if they were blocks and stones, nor does it abolish the will and its properties or coerce a reluctant will by force, but ... revives, heals, reforms, and - in a manner at once pleasing and powerful - bends it back (italics - BJvdW).

From these quotations it is clear that election, according to the Scriptures, does not imply an annihilation of human responsibility, but it should provide comfort to believers. Unfortunately it was confused with a theological problem at Dort.

\subsection{Different philosophical presuppositions}

Perhaps the most important conclusion (cf. 3.2 above) is that the real controversy at Dort was not between a correct interpretation of the Bible (the Calvinists) and a wrong one (the Arminians or Remonstrants). The clash between them occurred at a deeper, more foundational, philosophical level. In the case of Gomarus and Arminius it was probably a struggle between different interpretations of 
the same pagan Greek philosopher Aristotle (probably based on two different phases in his final development). The obvious reason is that what one confesses is influenced by one's worldview. Theologies are therefore defined, whether one is aware of it, like it or not, by philosophical presuppositions. (Philosophies are scholarly reflections on one's pre-scientific worldview, one's everyday heartfelt convictions of what both life and the world are all about.)

\subsection{Wording of the Confession}

In the light of my research on the customary viewpoint among reformed theologians (cf. Strauss, 2006; Coetzee, 2010), viz. that the content of the CD is fine, while only its form or wording may need some correction or updating, it is clear that this viewpoint has to be questioned (cf. 1.2.4 above). Words are not like empty containers, waiting for meaning (contents) to be poured into them. Words always have definite meanings - also in the CD.

The distinction between (often separating of) form or method, and contents or matter, has an age-old history that cannot be dealt with here. It first appeared clearly in Aristotle's work and was accepted by Thomas Aquinas, as well as reformed Scholasticism. Early Rationalism still emphasised contents, while later Rationalism place all emphasis on method. Bultmann and Kuitert later on tried to separate the contents (or real message) of the Bible from its cultural form or "packaging". Until the arrival of Irrationalism, however, methods were regarded as neutral tools in achieving knowledge.

We should, however, realise that form and contents (what you say and how you say it) are inseparable, as a method is not neutral, but always contains certain aims. It therefore defines the result of any investigation.

Vander Stelt (2012:39) correctly writes:

... it is not uncommon for Reformed theologians to think of the relation between philosophy and theology in terms of a relation between 'form' and 'content', how one thinks and what is thought, how doctrines are formulated and what is believed. The background of this widespread assumption in Reformed circles is a wider, more encompassing dualistic assumption about, for example, grace and nature, divine and human, sacred and secular, special revelation and general revelation, theology and philosophy, religion and science, faith and reason, authority and emancipation, obedience and projection, and objective and subjective knowledge. 
Any scholarly method is determined by one's deeper anthropological and ontological philosophical presuppositions. This is evident (cf. 3.3.2 above) in the case of the two scholastic methods - the socalled synthetic and analytic (not to be confused with Kant's distinction). Dort favoured the use of the more popular, non-theological, analytic method. However, this method was also defined by its basic dualist ontology of God and cosmos as the only two realities in one ontological hierarchy. While the synthetic method starts from God and moves downwards to the cosmos, the analytic method follows the opposite route, moving from the cosmos upwards to God.

Reformed Scholasticism, however, believed method and logic to be neutral gifts of God. Aristotelian logic was regarded as neutral with respect to Christian faith and, therefore, these theologians believed that it could not influence theological content.

\subsection{Supporting theological studies}

Since this article may be viewed (or even discarded) as that of a hyper-critical philosopher, I would note in conclusion that some reformed theologians have, in the light of a renewed study of the Bible, also raised concerns about how the CD viewed the relationship (in election and reprobation) between God and humankind. Limited space allows me to mention only a few examples.

Long ago, Holwerda (1958) provided an alternative interpretation of the phrase in Ephesians 1:4, viz. (that God elected) "before the creation of the world". According to him this expression simply refers to the establishment of Israel as a nation with its exodus from Egypt. The idea of an eternal decree should therefore be questioned. (Cf. also the study on Isaiah about the same issue in Dekker, 2010.)

Velema (1992) also challenged, from an exegetical perspective, many of the ideas expressed in the CD. He, for instance, indicates that God always elects within (or not prior to) history, acknowledging human faith and responsibility. (One should not only read Eph. 1:4 \& 1 Pet. 1:2, but also Phil. 2:12 \& Pet. 1:10.) The excellent contribution by De Boer and De Jong (2009) continues exegetical work in the same line.

\subsection{The authority of the Canons}

If it is impossible to simply correct the wording, form or method of the $C D$, how should one then view its authority? 
Should it be totally rejected? Updated? But how? Rewritten as a whole? By way of an appendix or postscript?

Another possibility is to make a distinction regarding its authority. It is proposed that reformed ministers, elders and deacons can subscribe to the CD either because (Lat.: quia), or only in so far as (Lat.: quatenus) it is in agreement with the Bible. The difficulty to be faced then is where to draw the line between the quia and quatenus. An even more important unsolved problem remains: in both the quia and quatenus viewpoints the authority of a fallible human confession is regarded as (either fully or at least partly) equal to God's authoritative revelation.

\subsection{Contemporary relevance}

Apart from the above, one should seriously consider the contemporary relevance of a confession authored nearly 500 years ago. I therefore have to disagree with the title the South African theologian, Van der Waal (1973), gave to his book on the CD: "Die Dordtse Leerreëls verdor nie" (The Canons of Dort do not wither). Some parts reflect the real biblical message and may, of course, still speak to the minds of contemporary Christians - at least to Western Christians - but not so much to, for example, African reformed believers. Moreover, many of the burning problems we are confronted with today are not addressed in the CD. In addition, the whole spirit of our times is different from that present 500 years ago, which makes it difficult for the CD to speak adequately to the hearts of present-day reformed believers.

\subsection{A personal viewpoint}

My own opinion is that the CD should neither be rejected nor improved, but be kept as an important historical document among many other confessions of the past (cf. Pellikan, 2003). Church officials should also not be required to subscribe to it per se, since it is not fully in agreement with God's Word.

Apart from that I am of the opinion that the primary aim of a Christian confession should not only be to judge (the negative) but to positively strengthen and inspire one's faith. (The Canons of Dort was originally not intended to be "the five points of Calvinism", neither to become a reformed confession together with the Belgic Confession and the Heidelberg Catechism, but only to pronounce a judgement about the errors of the Arminians. Cf. Sinnema, s.a.) 
At the same time we do sorely need contemporary, more relevant creeds, confessions or testimonies to really inspire Christians of today. Personally I would prefer Christian confessions indicating one's task in God's all-encompassing kingdom, instead of having to labour only on ecclesiastical and dogmatic quarrels. I agree with the assessment of Vander Stelt (2012:31) when he writes that for nearly 500 years protestant Christianity had focused too much, at times exclusively, on ecclesiastical matters and theological problems.

\subsection{A variety of Christian confessions}

Inspired by a biblically-obedient worldview - like the one Vollenhoven articulated - one has to realise that God's kingdom includes much more than the church and that other societal relationships should formulate their own credo's to express their own specific calling in God's encompassing kingdom. Examples of such non-ecclesiastical credos are, for instance, an educational creed for Christian schools, an academic credo for tertiary institutions, one for a Christian labour association, a Christian political party or a business enterprise. These kinds of "confessions" (today often referred to as mission and vision statements) are necessary, since ecclesiastical confessions are not intrinsically and directly focused on the implications of the gospel for these areas of life. If one, for example, tests scholarly work according to an ecclesiastical confession, one is implicitly subjecting such work to the control of a church, entailing in principle an infringement of the basic principle of sphere sovereignty. Scholarship is not the task of the church, neither is the church capable to adjudicate academic work. (The only exception may be where there is a close relationship between the church and theological education for future ministers.)

\subsection{Summa summarum}

We finally have to return to the basic query at the SD: the relationship between God and human beings. Could we solve this perennial, complex problem? The answer should be negative. Like most worldviewish philosophical issues it is an inevitable question (one is daily confronted with it), but simultaneously it is an enigmatic question. Since God is beyond human comprehension and also the human being is a mystery, it is impossible to have a full grasp of their mutual relationship.

At the same time it should be kept in mind that one may, from a wrong perspective, ask the wrong questions and consequently arrive at distorted solutions - I hope this article could draw attention to this 
important fact. In the full knowledge of our very limited and partial insights, we may at least conclude that we have arrived at a better answer than our predecessors in the reformed tradition. But we should never swear in the name of any theology or philosophy - all of which are merely fallible endeavours of us as human beings.

\subsection{A personal confession}

Perhaps the best way to conclude this article is to make a personal confession. It may read like this:

I sincerely believe in the absolute sovereignty of the triune God and I am also convinced that I need to act as a responsible human being. Even though it is beyond my comprehension how these two (God's work and my own responsibility) fit together, I hold to both convictions unswervingly because I know that, if I do not hang to both, I will go against God's infallible revelation in his Word.

\section{List of references}

AERTSEN, J.A. 1982. Natura et creatura: de denkweg van Thomas van Aquino. Amsterdam: VU Boekhandel.

AERTSEN, J.A. 1991. Thomas Aquinas (1224/5-1274). (In Klapwijk, J., Griffioen, S. \& Groenewoud, G., eds. Bringing into captivity every thought; capita selecta in the history of Christian evaluations of Non-Christian philosophy. Lanham: University of America Press. p. 95-122.)

BRIL, K.A. 1986. Westerse denkstrukturen. Amsterdam: VU Uitgeverij.

COETZEE, C.F.C. 2010. Belydenisgebondenheid in 'n postmoderne era. In die Skriflig, 44(1):27-46.

CRC (Christian Reformed Church), 1987. The Canons of Dort. (In Psalter Hymnal. Grand Rapids: CRC Publications. p. 927-949.)

DE BOER, E. \& DE JONG, H. 2009. Gedachtenwisseling over vragen rond verkiezing en verwerping. (In Bouma, J., Gerkema, F. \& Mudde, J., reds. Verrassend vertrouwd: een halve eeu verkondiging en theologie van Henk de Jong. Franeker: Uitgeverij Van Wijnen. p. 147-162.)

DEKKER, E. 1993. Rijker dan Midas: vrijheid, genade en predestinatie in de theologie van Jacobus Arminius. Zoetermeer: Boekencentrum.

DEKKER, J. 2010. De grondvesting der aarde: schepping en geschiedenis in het boek Jesaja. (In Van der Ziel, K. \& Holwerda, H., reds. Het stralend tellen: 60 jaar exegetische vergezichten van dr. D. Holwerda. Franeker: Uitgeverij Van Wijnen. p. 28-45.)

DEN OTTOLANDER, P. 1965. Deus immutabilis: wijsgerige beschouwing over onveranderlijkheid en veranderlikheid volgens de theologie van Sint Thomas en Karl Barth. Assen: Van Gorcum.

DOOYEWEERD, H. 1949. Reformatie en Scholastiek in de Wijsbegeerte. Franeker: Wever.

GRAAFLAND, C. 1987a. Van Calvijn tot Barth: oorsprong en ontwikkeling van de leer der uitverkiezing in het Gereformeerd Protestantisme. Zoetermeer: Boekencentrum. 
GRAAFLAND, C. 1987b. Gereformeerde Scholastiek. Deel 5: De invloed van de Scholastiek op de Gereformeerde Ortodoxie. Theologia reformata, 30:4-25.

GRAAFLAND, C. 1996. Van Calvijn tot Comrie: oorsprong en ontwikkeling van het verbond in het Gereformeerd Protestantisme. Deel 5: De OrthodoxGereformeerde en humanistisch-gereformeerde verbondsleer. Zoetermeer: Boekencentrum.

GRAAFLAND, C. 2001. Bijbels en daarom gereformeerd. Zoetermeer: Boekencentrum.

HOLWERDA, D. 1958. De grondlegging der wêreld: zag Israel zijn uittocht als schepping? Enschede: Boersma.

JANSE, A. 1937. "Mystiek" en "leven in het verbond". (In Janse, A., ed. Leven in het verbond. Kampen: Kok. p. 9-22.)

JANSE, A. 1939. Rondom de Reformatie. Goes: Oosterbaan \& Le Cointre.

KRUGER, J.P. 2011. Transcendence and immanence: a conversation with Jacques Derrida on space, time and meaning. Pretoria: UNISA. (D.Litt. et Phil. dissertation.)

KUNZ, A.J. 1996. Gods kennis en wil volgens de jonge Gomarus. Utrecht: Universiteit van Utrecht. (Doctoral thesis.)

LOVEJOY, A.O. 1973. The great chain of being: a history of an idea. Cambridge: Harvard University Press.

MULLER, R.A. 2003. Post-Reformation reformed dogmatics. 4 vols. Grand Rapids: Baker Academic.

MULLER, R.A. 2008. Christ and the decree: Christology and predestination from Calvin to Perkins. Grand Rapids: Baker.

NAUTA, D. 1957. Dordrecht, Synode van. (In Grosheide, F.W. \& Van Itterzon, G.P., reds. Christelijke Encyclopedie. Deel 2. Kampen: Kok. p. 485-488.)

PEELS, H.G.L. 2000. Heilig is zijn Naam: onze Godsbeelden en de God van de Bijbel. Bedum: Woord en Wereld.

PELLIKAN, J. 2003. Credo: historical and theological guide to creeds and confessions in the Christian tradition. New Haven: Yale University Press.

POLMAN, A.D.R. 1959. Leerregels, Dordtse. (In Grosheide, F.W. \& Van Itterzon, G.P., reds. Christelijke Encyclopedie. Deel 2. Kampen: Kok. p. 485-488.)

SCHAFF, P. 1983. Canones synodi dordrectanae, AD 1618-1619. (In Schaff, P., ed. The creeds of Christendom. Vol. 3. Grand Rapids: Baker. p. 550-557.)

SINNEMA, D.W. s.a. The Canons of Dort: from judgement on Armenianism to confessional standard. (In press.)

SINNEMA, D.W. 1985. The issue of reprobation at the Synod of Dort (16181619) in the light of the history of the doctrine. Ann Arbor: University Microfilms International. (Ph.D. thesis.)

SINNEMA, D.W. 1986. Reformed Scholasticism and the Synod of Dort (16181619). (In Van der Walt, B.J., ed. John Calvin's Institutes, his opus magnum. Potchefstroom: PU for CHE. p. 467-377.)

SINNEMA, D.W. 2002. Review of Van Asselt, W.J. \& Dekker, E. (2001): Reformation and Scholasticism. Calvin theological journal, 37:157-160.

SMITH, J.K.A. 2004. Introducing radical orthodoxy: mapping a post-secular theology. Grand Rapids: Baker Academic.

SPYKMAN, G.J. 1981. A new look at election and reprobation. (In Vander Goot, $H$., ed. Life is religion: essays dedicated to $H$. Evan Runner. St. Catherines: Paideia. p. 171-191.) 
SPYKMAN, G.J. 1992. Reformational theology: a new paradigm for doing dogmatics. Grand Rapids: Eerdmans.

STRAUSS, P.J. 2006. Die Dordtse tradisie en die binding aan die belydenis. In die Skriflig, 40(4):649-666.

TE VELDE, D. 2010a. Paths beyond tracing out:t he connection of method and content in the doctrine of God, examined in reformed orthodoxy, Karl Barth and the Utrecht School. Delft: Eburon.

TE VELDE, D. 2010b. Een positief beeld van Scholastiek. Beweging, 74(2):3437.

TOL, A. 2010. Philosophy in the making: D.H. Th. Vollenhoven and the emergence of reformed philosophy. Sioux Center: Dordt College Press.

VAN ASSELT, W.J. 1996. De erfenis van de gerformeerde Scholastiek. Kerk en theologie, 46:126-136.

VAN ASSELT, W.J. \& DEKKER, E., eds. 2001. Reformation and Scholasticism: an ecumenical enterprise. Grand Rapids: Baker.

VAN DEN BRINK, G., GEERTSEMA, H.G. \& HOOGLAND, J. 1997. Filosofie en theologie: een gesprek tussen Christen-filosofen en theologen. Amsterdam: Buijten \& Schipperheijn.

VAN DER WAAL, C. 1973. Die Dordtse Leerreëls verdor nie. Johannesburg: De Jong.

VAN DER WALT, B.J. 1968. Die wysgerige konsepsie van Thomas van Aquino in sy Summa Contra Gentiles met spesiale verwysing na sy siening van teologie. Potchefstroom: PU vir CHO. (M.A.-verhandeling.)

VAN DER WALT, B.J. 1974. Die natuurlike teologie met besondere aandag aan die visie daarop by Thomas van Aquino, Johannes Calvyn en die Synopsis Purioris Theologiae: 'n wysgerige ondersoek. Potchefstroom: PU vir CHO. (D.Phil.-proefskrif.)

VAN DER WALT, B.J. 2010. At home in God's world: a transforming paradigm for being human and for social involvement. Potchefstroom: The Institute for Contemporary Christianity.

VAN DER WALT, B.J. 2011a. Die gereformeerd-skolastieke visie op die verhouding tussen God en mens by I. Gomarus (1563-1641) en J. Arminius (1560-1609): 'n histories-filosofiese ondersoek. Tydskrif vir Geesteswetenskappe, 51(3):269-288.

VAN DER WALT, B.J. 2011b. Goddelike soewereiniteit en menslike verantwoordelikheid volgens die sintesedenke van ongeveer die $5 \mathrm{e}$ tot 17e eeu: 'n Christelik-filosofiese verkenning. Tydskrif vir Christelike wetenskap, 47(4):173-200.

VAN DER WALT, B.J. 2012a. Die invloed van die Aristotelies-skolastieke filosofie op die Dordtse Leerreëls (1619): 'n Christelik-filosofiese analise. Tydskrif vir Christelike wetenskap, 48(1): (ter perse).

VAN DER WALT, B.J. 2012b. Aristotelies-filosofiese invloede op die Sinode van Dordt (1618-1619) en die bevrydende perspektief van 'n reformatoriese filosofie op goddelike soewereiniteit en menslike verantwoordelikheid. Tydskrif vir Geesteswetenskappe, 52(2): (ter perse).

VAN ECK, J. 1997. En toch beweegt Hij: over de Godsleer in de Nederlandse belijdenisschriften. Franeker: Uitgeverij Van Wijnen.

VAN ITTERZON, G.P. 1956. Arminius. (In Grosheide, F.W. \& Van Itterzon, G.P., reds. Christelijke Encyclopedie. Deel 1. Kampen: Kok. p. 329-331.)

VAN ITTERZON, G.P. 1958. Gomarus. (In Grosheide, F.W. \& Van Itterzon, G.P., reds. Christelijke Encyclopedie. Deel 3. Kampen: Kok. p. 278-280.) 
VAN SCHAIK, J. 2005. In het hart is Hij te vinden: een geschiedenis van de Christelijke mystiek. Zeist: Uitgeverij Christofoor.

VAN 'T SPIJKER, W. 1990. Principe, method en functie van de theologie bij Andreas Hyperius. Kampen: Kok.

VANDER STELT, J.C. 2012. Faith life and theology: a reorientation. (In press.)

VELEMA, H. 1992. Uitverkiezing? Jazeker! Maar hoe? Kampen: Uitgeverij Van den Berg.

VOLLENHOVEN, D.H. Th. 1933. Het Calvinisme en de reformatie der Wijsbegeerte. Amsterdam: Paris.

VOLLENHOVEN, D.H. Th. 2000. Schematische kaarten: filosofische concepties in probleemhistorisch verband. Reds. K.A. Bril \& P.J. Boonstra. Amstelveen: De Zaak Haes.

VOLLENHOVEN, D.H. Th. 2005a. Isagôgè Philosophiae: introduction to philosophy. Bilingual ed. Ed. by J.H. Kok \& A. Tol. Sioux Center: Dordt College Press.

VOLLENHOVEN, D.H. Th. 2005b. De probleem-historische methode en de geschiedenis der Wijsbegeerte. Red. door K.A. Bril. Amstelveen: De Zaak Haes.

VOLLENHOVEN, D.H. Th. 2005c. The problem-historical method and the history of philosophy. Ed. by K.A. Bril. Amstelveen: De Zaak Haes.

VOLLENHOVEN, D.H. Th. 2011a. Getuigen in de wetenschap \& wijsbegeerte en teologie. (In Bril, K.A. \& Nijhoff, R.A., reds. Vollenhoven, D.H. Th. Gastcolleges Wijsbegeerte: erfenis voor het heden. Amstelveen: De Zaak Haes. p. 189-200, 201-214.)

VOLLENHOVEN, D.H. Th. 2011b. Gastcolleges Wijsbegeerte: erfenis voor het heden. Reds. K.A. Bril \& R.A. Nijhoff. Amstelveen: De Zaak Haes.

\section{Key concepts:}

Arminius, J. (1560-1609)

Christian philosophy

God-human relationship

Gomarus, F. (1563-1641)

reformed Scholasticism/Orthodoxy

Synod/Canons of Dort

Vollenhoven, D.H. Th. (1892-1978)

\section{Kernbegrippe:}

Arminius, J. (1560-1609)

Christelike filosofie

gereformeerde Skolastiek/Ortodoksie

God-mens verhouding

Gomarus, F. (1563-1641)

Sinode/Leerreëls van Dordt

Vollenhoven, D.H. Th. (1892-1978) 